\title{
Environment and Economic Analysis of Solar Plant Construction in Chile
}

\author{
TIANLE ZHANG, XIANGSAI FENG, XU ZHU \\ Shanghai Solar Energy Research Center, Shanghai 200241, China \\ zhangtianle@solarcell.net.cn, fengxiangsai@solarcell.net.cn \\ zhuxu@solarcell.net.cn
}

Keywords: Photovoltaic Power Station, Chile, Preliminary Analysis.

Abstract. This project discussed environment and economic situation including regulation, deployment and Financing of building solar plant in Chile, which provided flexibility for further project construction.

\section{Introduction}

The economic expansion of Chile has led to a GDP growth of over 170\% in the last 10 years [1], pushing up the demand for electricity, which has been covered by a steady raise of its production, from 42.2 TWh in 2002 to $65.8 \mathrm{TWh}$ in 2012 [2]. Due to its geography, Chile presents five major independent electric transmission systems. The main two, providing 99\% of the country's energy [3], are the SIC (Interconnected Central System) in the centre of the country and the SING (Interconnected System of the Grand North), covering the northern most $800 \mathrm{~km}$ of the territory [4]. In 2013 the SIC generated 47.8 TWh, while the SING generated 15.4 TWh [3]. The electricity supply generated in SING is $99 \%$ fossil fuel dependent [5]. At the country level, hydro energy coversaround one third of the electricity generated [5], while more than $60 \%$ of it is produced from fossil fuels, which are almost entirely imported [6], while around one third is provided by hydro energy [5]. This structure has affected the security of the electricity supply in the past, due to specific climatic events (that altered the hydro-electricity generation) and due to fuel import problems [4] [7]. Over the years, copper mining has been the main consumer of electricity in the country, requiring $32 \%$ of the total. This number reached 83\% in the SING zone in 2013 (12.8TWh from a total of $15.414 \mathrm{TWh}$ ) [9] [3].

To improve the security of electricity supply, the Chilean government has recently adopted policies to support projects that harvest non-conventional renewable energies (NCRE). The target for the electricity produced by NCRE is set at $20 \%$ of the domestic demand by 2025 [10]. As a reference: the share of solar generation by 2013 was $0.02 \%$ in the SING and $0.01 \%$ in the SIC [5].

\section{Solar Projects in the SING}

Currently, numerous solar projects are being developed in the North of Chile. With the different changes in the regulations [10], the technology price decreasing and the high price of the energy in the country (above 90 USD/MWh in 2014), it has become viable for these projects to be deployed without government subsidization [11]. The scale of this trend becomes evident when looking at the latest process of onerous concessions for land (i.e. renting of state land) for energy projects in the North of Chile, run by the government. From 11,537 hectares offered, 8,246 hectares were assigned to solar projects, planned to provide 1,970 MW of installed capacity, with a total investment of 4548 million USD [12]. As reference, by 2014 the total installed capacity of the SING was 4,177MW [13].

The figures below show the heavy reliance of the SING expansion plan (in terms of generation) on solar energy. In the near future there will be, in average, around $170 \mathrm{MW}$ of new solar generation capacity added to the SING per year, while fossil fuel based generation will reach approximately 265 MW of increment per year. 


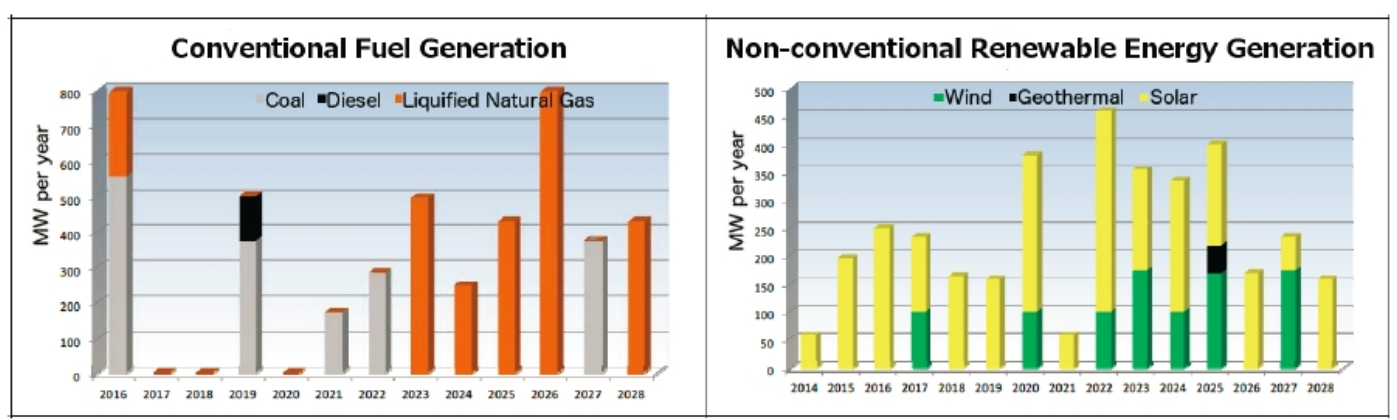

Figure 1: Expected generation projects in the SING. Conventional fuels (left) and nonconventional renewable energies (right)

\section{Definition, justification and limits of the present work}

\section{Definition and limits of the project}

The following sections will present the steps involved in the development of a solar photovoltaic (PV) generation plant in the Atacama Desert, specifically in the Antofagasta region, in Chile.

The power to be delivered by the plant will be 100MW. It is outside the aim of this work to state whether the produced electricity will be sold to a specific consumer or if it will be delivered to the SING grid. Nor will it state a specific location for the plant, or a specific connection point to the grid. There are several substations spread over the region, which may provide access to the SING grid. Most of them also signal locations close to main consumers of electricity (e.g. mineral mines). It is important to note that the SING network is constantly undergoing upgrades to expand its capacity and coverage, to supply new or existing clients (consumers and generators) with enough transmission capacity. Therefore, we can assume the availability of sufficient transmission capacity for new solar projects in the area .

The base idea of this project is to create a generic scheme that can be applied to different locations and potential consumers. There is also enough free space in its $105,000 \mathrm{~km}^{2}$ without competing activities, to dismiss restrictions for the plant deployment. Considering this approach, the focus will be set in the definition of the photovoltaic panels array design, the inverter characteristics and their interconnection and the supporting electrical infrastructure.

\section{Justification of Site}

\section{Solar energy in Chile}

The location for the solar plant investment was chosen in the basis of a number of factors. Firstly, the climatic conditions are exceptionally favourable for harnessing solar energy. The Atacama Desert in Chile experiences one of the highest irradiance levels worldwide, with annual values around 2700 $\mathrm{kWh} / \mathrm{m}^{2}$ of global horizontal irradiance (daily: $7.5 \mathrm{kWh} / \mathrm{m}^{2}$ or higher).

As a reference for the climatic conditions, a location in the desert was chosen, namely $-22.5^{\circ} \mathrm{N}$, $-68.9^{\circ} \mathrm{E}$. Elevation for this location is $2320 \mathrm{~m}$. This fact must be taken into account in the design of the electric system, since all equipment must be certified to be fully functional at this altitude. Table 1 displays a set of atmospheric variables to be considered in the design phase. The relatively low average temperatures can be explained by the large temperature differences between day and night at altitudes like the chosen location. The average day temperature is $22.9^{\circ} \mathrm{C}$, while night temperature has an average of $1.8^{\circ} \mathrm{C}$. From May to September night temperatures might be even slightly negative . All chosen equipment must, therefore, be able to cope with frequent and extreme temperature variations. Another critical aspect affecting photovoltaic panel efficiency is humidity. Relative humidity has two negative effects on the power output of PV cells. Firstly, humidity in the atmosphere lowers irradiance levels. Secondly, water vapour in the panels leads to degradation of the cells themselves, reducing their current output is . The Atacama Desert exhibits preferable conditions in this regard, as relative humidity is generally low throughout the year. 
Lastly, the high irradiance level and a nearly non-existent cloud cover make the Atacama Desert a highly profitable location for large scale solar energy projects. This potential has been recognized by solar energy development firms from all over the world and investments have risen sharply in recent years, as mentioned before. In the latter years Chile has developed a favourable regulatory framework to make the country attractive to (foreign) investment. In The World Bank ranking measuring the ease of doing business, published in 2013, Chile ranks 37th worldwide due to its unbureaucratic processes for creating businesses. The previous, in addition to several mechanisms implemented by the government that foster NCRE exploitation, helped to achieve $185 \mathrm{MW}$ of installed capacity and to have another $450 \mathrm{MW}$ under construction by July 2014. All of these projects are financially viable without subsidies from the state [11]. Newer, bigger projects are constantly started, which makes Chile to be well underway to meet its target of $20 \%$ renewable electricity generation by 2025 . Lastly, Chile is also an attractive market considering demand side conditions. Mining projects are large scale customers for the produced electricity of PV arrays. The electricity demand in the SING, which is governed by the copper mining industry, has been rising steadily over the past years and is expected to rise further. According to SING projections, a constant increase in its installed generation capacity will be required, to jump from 2,100 MW in 2014 to 5,200 MW in 2028 . In another front, the price of electrical energy in the SIGN is expected to stay steady after 2016 at around 80 USD/MWh. All these factors make the long term prospects promising for solar proyects.

\section{Project Adjacent Considerations}

\section{Regulations}

The minimal technical requirements stated by the SING for the connection of generation capacity to its line were considered as a guiding rule when needed in our study, since similar conditions may apply to connect to any customer. Regarding environmental regulations, given the characteristics of the project and its settlement, only an Environment Impact Declaration and not a full study is required . Solar projects of similar capacity have proceeded this way .

\section{Deployment}

To ease the logistics, the solar plant to build should be located near to a city (i.e. less than $100 \mathrm{Km}$ away) to avoid long commuting. This should ease the provision of accommodation, catering and general services and supplies. The area is not densely populated and hence this may set restrictions for the plant location, influencing the price to pay for the land to use.

\section{Financing}

Projects of similar size are currently being installed by SunEdison in the Atacama Desert. Comparing their finance model offers some insight into potential institutions offering finance support with solar PV projects of this magnitude. For SunEdison's plants Amanecer Solar CAP (100MW), San Andres (50.7MW) and Maria Elena (72MW, planned), the firm managed to secure loans from the Overseas Private Investment Corporation (OPIC), International Finance Corporation (IFC) of the World Bank Group, InterAmerican Development Bank (IDB), the Clean Technology Fund (CTF) and from private banks such as CorpBanca (Chile) and Rabobank (Netherlands). In total, a number of 35 investors were involved in the development of the San Andres power plants, which suggests a large share of debt financing and only little contribution of equity capital by SunEdison. However, most of the deals are made for non-recourse debt, meaning that the loans are backed with collateral. It can be assumed that the equipment of the plant constitutes this guarantee for the lenders in case of bankruptcy of the borrower. For the financing scheme of the designed plant we have therefore chosen to finance the major part of the equipment with external debt, representing a share of $60 \%$ of the total costs. 


\section{Conclusion}

Despite the vast potential the Atacama Desert in Chile offers to solar PV developments, investors have to keep in mind factors of potential customers, the possibility of regulatory changes, and technical risks. These factors may limit financial profitability in the future. However, nowadays Chile appears to be the most attractive market for utility scale projects. The current energy needs of an expanding mining industry and, in the near future, the announced connection of the SING and the SIC (central grid, feeding the vast majority of the population and industry), makes the Atacama desert a promising ground for future investment in solar energy projects. If there is a real explosion of projects in the future, a risks to be assessed would be, on the economic perspective, the saturation of the electrical market, which may lead to a drop in the electricity price, forecasted until now at $80 \mathrm{US} \$ / \mathrm{MWh}$ for the SING. A not minor risk, which unfortunately cannot be forecasted, is the seismic nature of the country. Hence, the entire infrastructure needs to be built according to seismic standards.

\section{Reference}

[1] The World Bank, "Data - GDP," 2015. [Online]. Available: http://data.worldbank.org/indicator/NY.GDP.MKTP.CD. [Accessed 21 Mar 2015].

[2] OECD, "Electricity Generation," 2015. [Online]. Available: http://data.oecd.org/energy/electricity-generation.htm\#indicator-chart. [Accessed 21 Mar 2015].

[3] Comision Nacional de Energia, Chile, "Producción real por sistema," 2013a.

[4] IEA, "Oil and Gas Security - Chile," 2012. [Online]. Available:

http://www.iea.org/publications/freepublications/publication/chile_2012.pdf. [Accessed 5 Dec2014].

[5] Ministerio de Energia, "Agenda de Energia," Ministerio de Energia, Chile, 2014.

[6] IEA, "IEA Statistics," 2014d. [Online]. Available:

http://www.iea.org/statistics/statisticssearch/report/?

year=2012\&country=CHILE\&product=Balances. [Accessed 5 Dec 2014].

[7] IEA, “CHILE ENERGY POLICY REVIEW 2009,” OECD/IEA, 2009.

Consejo Minero, "Energia y cambio climatico," 2014. [Online]. Available:

http://www.consejominero.cl/ambitos-estrategicos/energia-y-cambio-climatico/. [Accessed $21 \mathrm{Mar}$ 2015].

[8] Comision Chilena del Cobre, "Proyeccion del consumo de energia electrica de la mineria delcobre en Chile al 2025,” 2013.

[9]Ministerio de Energia, "Gobierno promulga Ley 20/25 y anuncia entrada en vigencia de Ley deConcesiones," 14 Oct 2013a. [Online]. Available:

http://www.minenergia.cl/ministerio/noticias/generales/gobierno-promulga-ley-20-25-yanuncia. html. [Accessed 5 Dec 2014].

[10] C. Roselund, "Chile's solar market is leading the way in South America," 05 Jun 2014. [Online]. Available:

http://www.theguardian.com/global-development-professionalsnetwork/2014/jun/05/chile-renewable -energy-solar-power. [Accessed 22 Mar 2015].

[11]Ministerio de Bienes Nacionales, "Bienes Nacionales aprueba concesiones para la ejecución de43 proyectos de Energías Renovables No Convencionales," 17 May 2014. [Online]. Available:

http://www.bienesnacionales.cl/?p=10912. [Accessed 21 Mar 2015].

[12] Comision Nacional de Energia, "Estadisticas Electricidad," 2014. [Online].

Available:http://www.cne.cl/images/Capacidad\%20Instalada\%20de\%20generaci\%C3\%B3n.xls.

[Accessed 22 Mar 2015].

[13]Direccion de Peajes CDEC-SING, "Propuesta de Expansion del Sistema de Transmision del SING," CDEC-SING, 2014. 